\title{
The Implementation Of ERP In Supply Chain Management On Conventional Woven Fabric Business
}

\author{
Julianty Surasma Surung \\ Department of Information Technology, Faculty of Engineering, Udayana University, Bukit Jimbaran, Bali, Indonesia \\ Email: yanthysurung@gmail.com \\ I Putu Agung Bayupati and Gusti Agung Ayu Putri \\ Department of Information Technology, Faculty of Engineering, Udayana University, Bukit Jimbaran, Bali, Indonesia \\ Email: bayupati@it.unud.ac.id and agung.ayuputri@unud.ac.id
}

Received: 06 January 2020; Accepted: 03 February 2020; Published: 08 June 2020

\begin{abstract}
The development of modern technology requires companies to increasingly compete. It does not only apply to big companies but also small companies like Micro, Small and Medium Enterprises (MSME). In Indonesia, most MSME runs without the use of information technology, one of which is the XYZ weaving conventional business. The XYZ Weaving Business is a manufacturing company that produces products in the form of Endek Fabrics and Custom Fabrics. Endek is a term for ikat woven fabric originating from the island of Bali. Endek woven fabric has a variety of unique motifs from sacred to reflect the feel of nature. Meanwhile, custom weaving is a term for woven fabric that has a homemade motif and usually comes from the wishes of the customer. The business has an income above 50 million rupiahs every month with a total production of 2000 meters of fabric, besides, their customers are from companies and individuals. However, their processes are still managed conventionally, resulting in internal problems such as unorganized data and information due to the lack of integration among company divisions. Furthermore, it also results in disrupted service to customers and the company could suffer losses. ERP is a very popular concept to use in companies because it has a functional area that suits the needs of the company. The ERP used in this study is based on Open source, namely Odoo. The results of research with the implementation of Odoo software by using the Sales, Purchase, Inventory and Manufacturing modules resulting in a more integrated business process change. A test was conducted by using the User Acceptance Testing method to 10 respondents consisting of marketing company employees, administrators, material purchases, warehouses, and production. The total score obtained is 713 and is located in the third quarter, which means the system is considered quite successful to be implemented in XYZ Weaving.
\end{abstract}

Index Terms-Enterprises Resource Planning, Supply Chain Management, MSME, Odoo, User Acceptance Testing

\section{INTRODUCTION}

Micro, Small and Medium Enterprises (MSMEs) are businesses that have a relatively small income scale. MSME businesses include culinary businesses, fashion businesses, and agribusiness, etc. The businesses often run individually or in groups. One of the examples of MSMEs is the textile industry. Currently, it has become an economic source for every region by producing textile products such as woven fabric. It becomes a potential because of the artisan's creativity and innovations from every business that follows modern developments. Based on data from the Ministry of Industry of the Republic of Indonesia, the textile industry can make a significant contribution to the national economy with its exports by reaching USD 151.7 million in 2016. With a large export potential, it is expected that significant growth will occur in the weaving industry. As a result, it can increase national economic growth [1].

The MSME need to manage their business processes to be more efficient and appropriate to manage the accuracy of data and meet customer needs, therefore it is profitable. They can implement the system as a tool to help in managing each part of the company into one unit. For MSME companies with a minimum income, many applications and tools fit the company's needs without having to pay expensive fees.

XYZ Weaving has been established since 1991 and located in Gianyar-Bali. It produces 2000 meters per month of Endek cloth and Custom Woven Fabrics with an income above 50 Million Rupiah. Endek is a term for ikat woven fabric originating from the island of Bali. 
Endek woven fabric has a variety of unique motifs from sacred to reflect the feel of nature. Meanwhile, custom weaving is a term for woven fabric that has a homemade motif and usually comes from the wishes of the customer. The XYZ weaving is still managed manually where each department is managed by using only Microsoft Excel for data collection and reports. This is certainly a problem for companies. They will have slow information from inventory if the sales department requires stock information in real-time because stock calculations are done manually. This manual process also results in the occurrence of Human Error, therefore the accuracy of data and information is disrupted. Furthermore, the process of purchasing goods to vendors that are not following market demand resulting in excess and lack of stock in the warehouse.

The management process in MSME companies will be better if it is implemented by technology. It aims to integrate the company's departments to be able to overcome management problems manually. One integrated technology approach for companies that are popular these days is the application of Enterprise Resource Planning (ERP) systems. ERP is an application that has functional areas, such as Marketing and Sale (M/S), Accounting \& Finance (AF), Supply Chain Management (SCM), and Human Resources (HR). The ERP software is suitable for MSME companies because it is based on Open Sources such as Compiere, Openbravo and Odoo [2].

This study uses an ERP application called Odoo to be implemented to XYZ Weaving. Not only it is based on Open source, but Odoo can also be customized according to the needs of the company. Therefore, it can help in managing business processes more efficiently, easily, and integrated. Customization will be carried out on the company's SCM as in the inventory. Manufacturing is done by using the reordering rules feature to manage inventory schedules in the warehouse both in the process of purchasing material and production. This can provide convenience in getting the accuracy of the amount in the process of purchasing to the vendors. As a result, the supply in the company can maximize the capacity of the warehouse and the company does not become a loss.

\section{THEORETICAL FRAMEWORK}

\section{A. Enterprise Resource Planning (ERP)}

Enterprise Resource Planning (ERP) is an application that integrates information into all divisions in an organization by combining information into one single database. The database can be stored locally if the ERP implementation is done at the company premises, it also can be a cloud-based if the ERP system implementation is outside the organizational boundaries. The government also made an effort in using technology, such as the implementation of ERP globally to improve services to citizens, have better governance and transparency as well as to have a smoother workflow. According to Davenport the government's reason for adopting an ERP system is that it can help in forming government organizations to solve the challenges of the old uncoordinated application portfolio. Besides, ERP systems provide an uninterrupted integration of all information flowing in an organization. The ERP provides an open-source system, therefore it can help to save costs for developing MSMEs who cannot make much investment in IT infrastructure, software and hardware, and IT staff. Theoretically, ERP has a functional operating area that covers all organizational needs, such as Marketing and Sale (M/S), Supply Chain Management (SCM), Accounting and Finance (AF) and Human Resource (HR). This research implements some parts of the ERP operations area, which is the SCM area. The SCM consists of several business functions related to warehouse and logistics. The business functions applied in this study as shown in Figure $1[3,4,5,6,7,8]$.

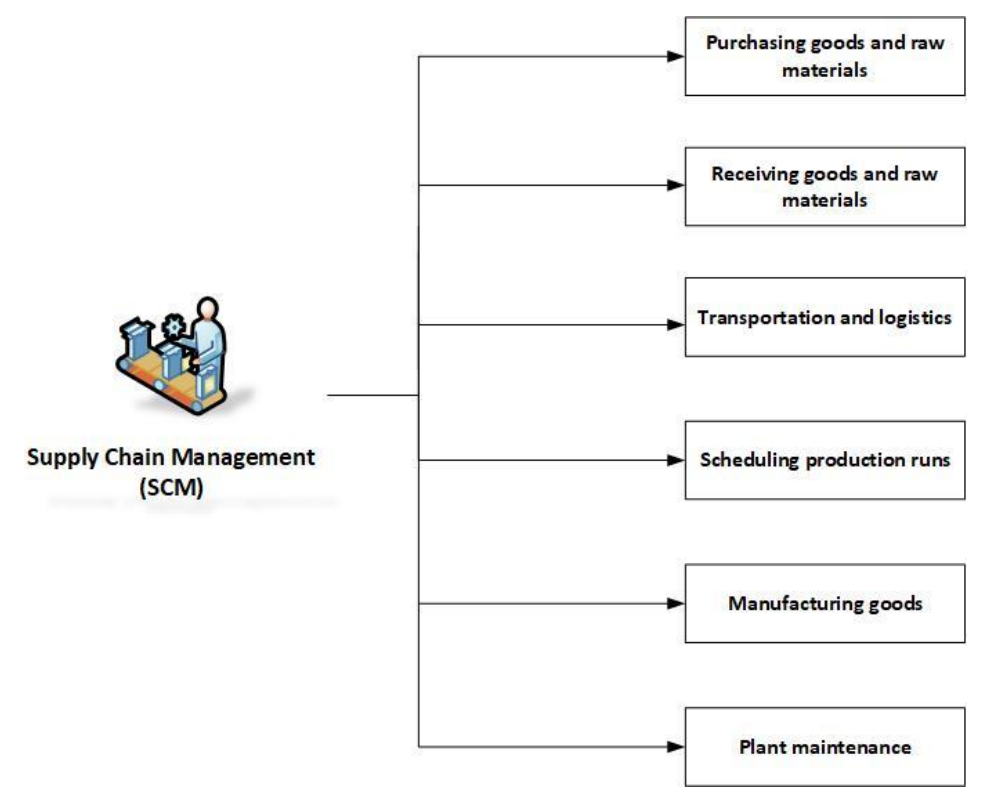

Fig.1. SCM business functions (Source: Concepts in Enterprise Resource Planning, Fourth Edition) 
Supply Chain Management (SCM) is a process of managing the flow of goods which includes 6 functions. The process of purchasing products and materials to vendors is a function to collect data on the receipt of products and materials. The transportation and logistics function means the process of managing the material movement and product delivery to the customer. Scheduling production runs function as a model for scheduling the purchase and production of goods or it is a form of safety stock to maintain the company's warehouse capacity to be more accurate and save costs. The function of manufacturing goods is the process of managing the production of goods which is displayed with production time to estimate delays and there is supervision at each stage of production. The sixth function is plaint maintenance where it maintains production facilities and it is usually used by large companies or factories to minimize delays in production.

The application of technology is not only for large companies but also for MSMEs. Therefore, it helps to optimize service and customer satisfaction, also, to be able to maintain its business in the modern market. The developed ERP is free which can be applied directly to MSME companies with minimal costs. The book written by Noprianto et al explains that OpenERP (the initial name was TinyERP, now better known as Odoo) is one of the most widespread ERP software for free development. The ERP software can provide enormous benefits for a company that helps manage company resources, therefore the resources owned by the company can be recorded, controlled and easy to be empowered [9].

\section{B. User Acceptance Testing (UAT)}

The success rate measurement of the success rate of system implementation can use several methods, for example, Use Questionnaire, Technology Acceptance Model (TAM), Critical Success Factor (CSF), and User Acceptance Test (UAT). Use Questionnaire is a measurement of the usefulness of the system with the use of 3 aspects, such as easy to compare, namely effectiveness, efficiency, and satisfaction. The Technology Acceptance Model (TAM) was proposed by Fred Davis in 1986 to study the acceptance of newly developed information systems and to find out the benefits and ease of using the system. The Critical Success Factor (CSF) is an analytical method by considering the critical things in the company and knowing the impact of various success factors on the system implementation process. Furthermore, this study used a method to determine user acceptance of the system called the User Acceptance Test (UAT) method. It is a form of test for software developers by giving directly to the audience to find out their level of acceptance. This method is so innovative that it can prevent the failure of an Information Technology project. This method is conducted by end-users or clients who have the main reason to identify the processes performed by the system and can be useful for them before the system is implemented in a real environment. The UAT method consists of White Box and Black Box. The White box is a test performed by the developer and the black box is a test performed by the end-user in the form of a document to determine the feasibility of the system. There are also tests conducted to measure respondents' attitudes by using a Likert's Summated Rating (LSR) scaling technique on the results of the questionnaire. The LSR is very useful for comparing a person's attitude score with the scale distribution of another group of people $[10,11,12,13]$.

\section{RELATED WORKS}

Research on the impact of ERP systems on public sector organizations succeeded in proving that implementing a new system in organizations is an efficient strategy for performance efficiency and increasing organizational effectiveness. A research on the use of ERP systems in SMEs tells ERP is very important for SMEs from a strategic point of view, especially the competitive economic environment encountered in global business that focuses on reducing costs and prioritizing customer needs. Research on evaluating the ERP concept of MSME business regarding the selection of ERP applications based on the features provided shows the OpenERP application becomes the best open source ERP system for small and medium-sized companies. The ERP implementation was also performed in the marketing department shows that the use of Odoo applications can overcome sales problems in the company. A research on the development of the SCM system which shows that the use of ERP concepts can make a company's business processes best practice $[2,5,7,14,15]$.

\section{METHOD}

ERP implementation in XYZ Weaving includes six steps which can be seen in the following figure 2 .

This research literature listed in related works refers to research to explore research methods and system configuration methods in Odoo, therefore it can be adjusted to the needs of the company. The data collection stage is conducting interviews with XYZ Weaving to get the flow of existing business processes as well as sales, data warehouse and direct observation to see the production process. The data analysis stage is analyzing the company's business processes and making proposed business processes using Odoo. By using Odoo, it is expected to help facilitate the process of purchasing, producing and managing the warehouse in a woven fabric company. Data processing implies Odoo where the configuration is made in the Purchase, Inventory, Manufacturing module following the needs of the woven fabric company. Furthermore, a test is conducted to determine the feasibility of the Odoo system. If it is feasible, then it proceeds by making conclusions. If it is not feasible, then the test will be repeated in the Odoo application. 


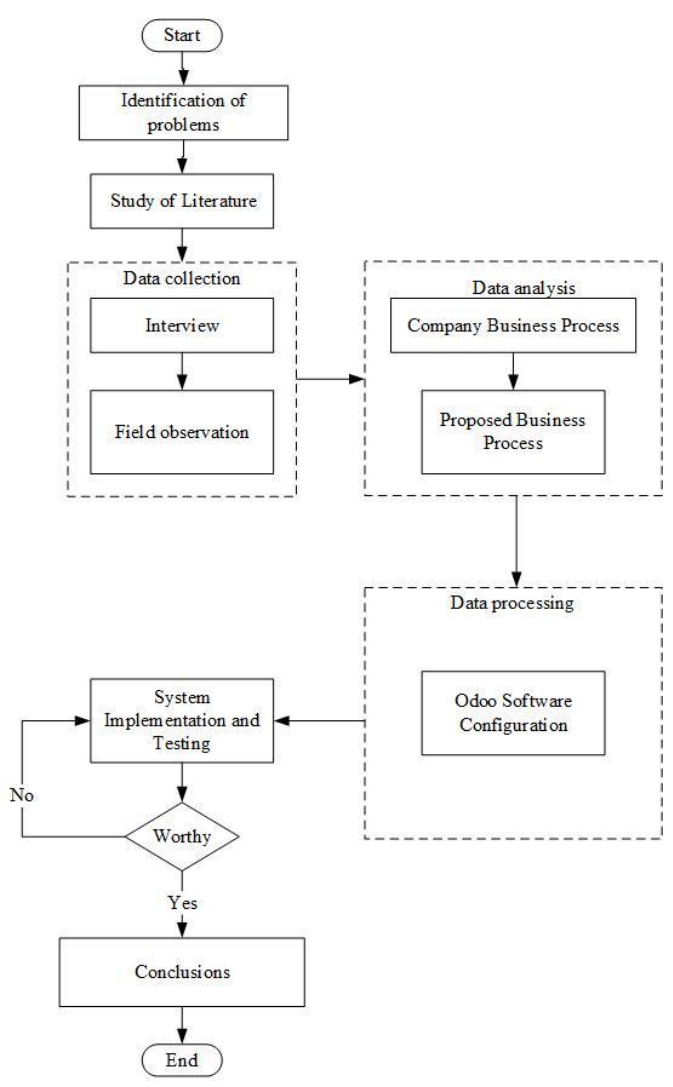

Fig.2. Research Flow Chart

\section{RESULt AND ANALYSIS}

The business process of XYZ Weaving is still running conventionally. In this study, the concept of ERP based on Odoo application on the SCM process of XYZ Weaving can be seen in Figure 3.

Figure 3 is an implementation of Odoo including the Website, Sales, Invoicing, Manufacturing, Purchases and Inventory modules. The Odoo website is used as a way of selling to get customers widely and then they can also order products. The sales module is used to get and make quotations. The quotations are used to discuss prices between Customer and sales. Then, the quotations made through the website will enter the Sales module which will be validated to create a Sales Order. The Invoicing Module is a module for managing and validating payments from customers and payment of invoices to Vendors. The Manufacture module contains a BoM (Bill of Material) or a list of material requirements used for each product, the making of routes and the stages of the work of each incoming order. The Purchase Module is used to make procurement automatically when the raw material stock has reached the minimum limit. Furthermore, validating the Purchase Order which is a document containing a list of materials purchased at the Vendor and making a draft vendor bill or temporary purchase invoice document that will be validated by Accounting in the Invoice module. Then, the vendor receives a Purchase Order and also a payment note. The Inventory Module is used to view stock data, delivery order data, and validates it when the goods are sent to the Customer.

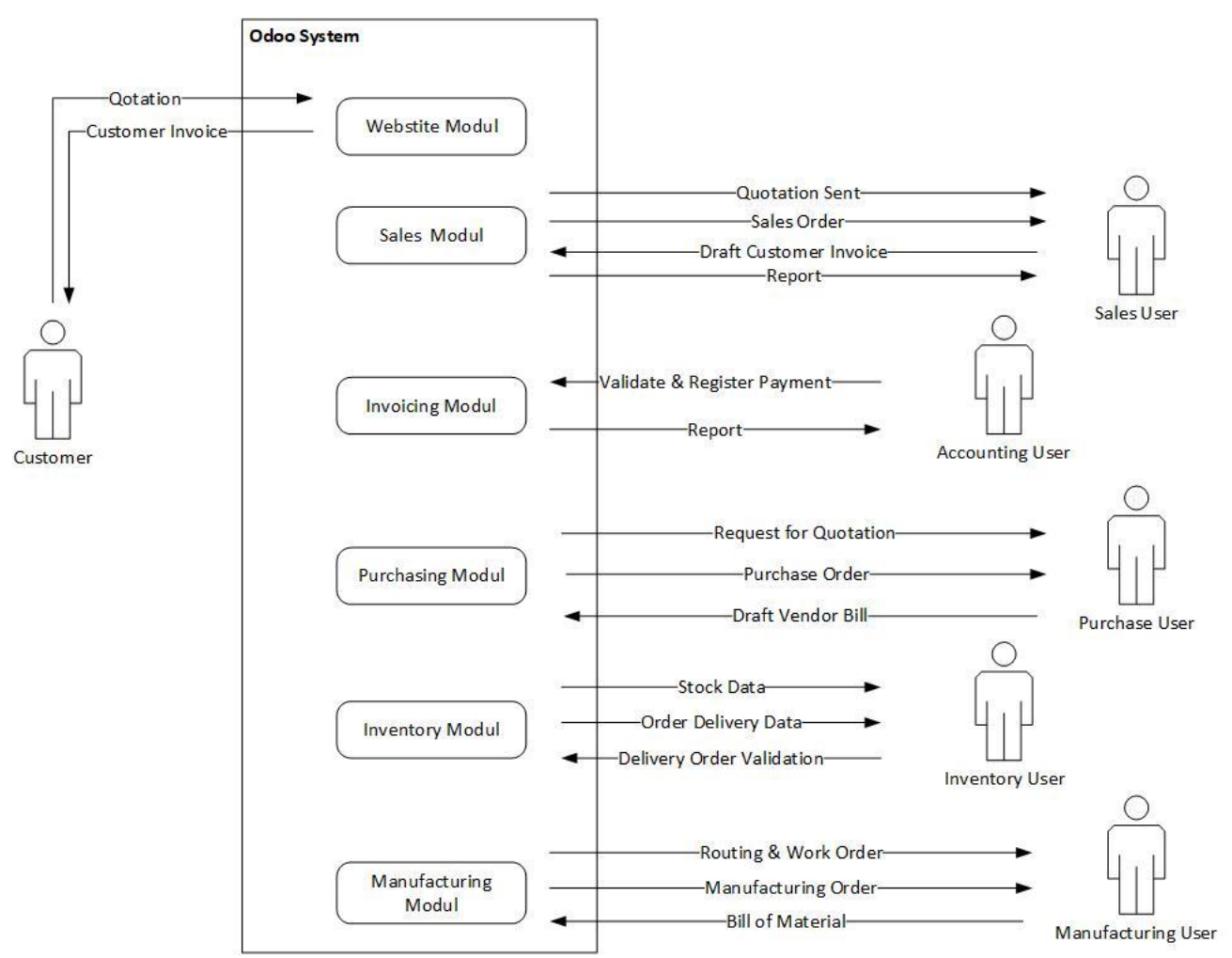

Fig.3. Overview of Odoo Implementation 


\section{A. Display of the Application}

MSMEs can build and design websites on Odoo software by using a website module which can then be hosted on the server. The research on XYZ Weaving is still a design that is run from the localhost. The results of configuration and customization can be seen in Figure 4 .

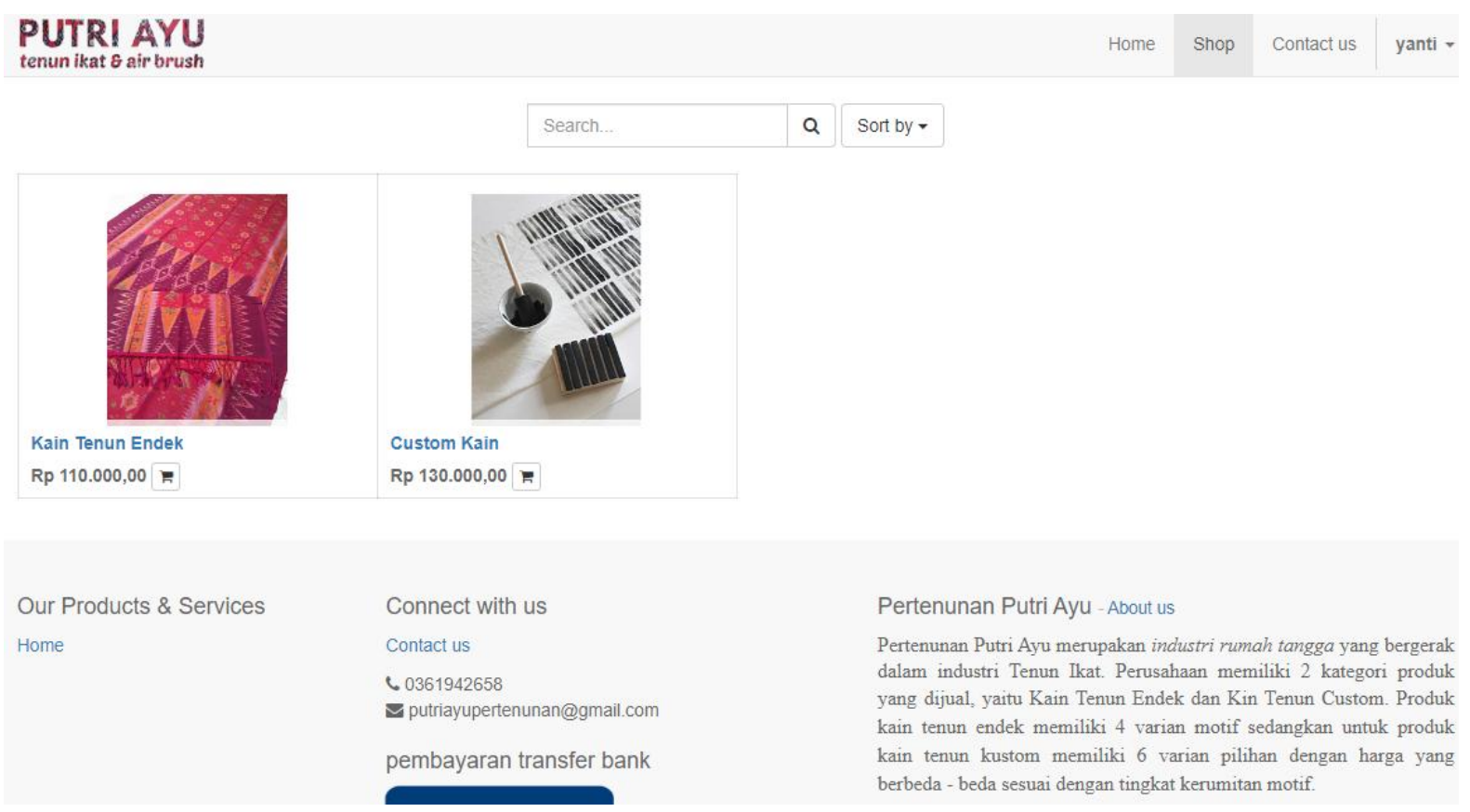

Fig.4. Product Website offered

Figure 4 displays the categories of products sold by companies, such as Endek Fabric and Custom Fabrics. Next, the fabrics are chosen by customers from outside the company. Then, the variety and prices of each product will be displayed.

\section{SO020}

\begin{tabular}{l|ll|} 
Customer & yanti & \multicolumn{1}{l}{ Expiration Date } \\
Jl Binginsari gang II Jimbaran - Kuta & Payment Terms & Immediate Payment \\
& $\begin{array}{l}\text { Selatan } \\
\text { Badung BA 80362 } \\
\text { Indonesia }\end{array}$ & \\
Invoice Address & yanti \\
Delivery Address & yanti \\
Quotation Template & Default Template
\end{tabular}

\begin{tabular}{|c|c|c|c|c|c|c|c|c|c|c|}
\hline \multicolumn{2}{|r|}{ Order Lines } & \multicolumn{2}{|c|}{ Suggested Products } & \multicolumn{7}{|c|}{ Other Information } \\
\hline- & Product & & Description & & $\begin{array}{r}\text { Ordered } \\
\text { Qty }\end{array}$ & $\begin{array}{l}\text { Unit of } \\
\text { Measure }\end{array}$ & $\begin{array}{l}\text { Analytic } \\
\text { Tags }\end{array}$ & $\begin{array}{r}\text { Unit } \\
\text { Price }\end{array}$ & Taxes & Total \\
\hline & $\begin{array}{l}\text { Custom Ka } \\
\text { Uniform, M }\end{array}$ & $\begin{array}{l}\text { Bahan } \\
\text { h) }\end{array}$ & $\begin{array}{l}\text { Custom Kain } \\
\text { Uniform, Mud }\end{array}$ & $\begin{array}{l}\text { (Bahan } \\
\text { ah) }\end{array}$ & 10,0 & $\mathrm{~m}$ & & 115.000 & & Rp $1.150 .000,00$ \\
\hline
\end{tabular}

Fig.5. Sales Order Form

Figure 5 shows the making of a quotation from $\mathrm{SO} 020$ which is confirmed to be a sales order from a sales user. It is confirmed by selecting the "Confirm Sale" button. Then the status moves to a sales order. The function of the quotation itself is an intermediary for discussion. When a customer's order does not comply with the order conditions, it can be canceled and a new quotation is conducted by the customer. 


\section{Purchase Order}

PO00001

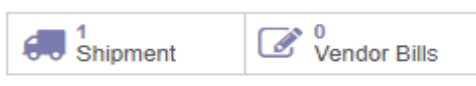

\begin{tabular}{l|l} 
Order Date & 06/09/2019 21:05:31
\end{tabular}

Source Document $\quad$ OP/00002

\begin{tabular}{|c|c|c|c|c|c|c|c|c|c|c|c|c|}
\hline \multicolumn{2}{|r|}{ Products } & \multicolumn{11}{|c|}{ Deliveries \& Invoices } \\
\hline 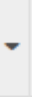 & Product & Description & $\begin{array}{l}\text { Scheduled } \\
\text { Date }\end{array}$ & $\begin{array}{l}\text { Analytic } \\
\text { Account }\end{array}$ & $\begin{array}{l}\text { Analytic } \\
\text { Tags }\end{array}$ & Quantity & $\begin{array}{r}\text { Received } \\
\text { Qty }\end{array}$ & $\begin{array}{r}\text { Billed } \\
\text { Qty }\end{array}$ & $\begin{array}{l}\text { Product } \\
\text { Unit of } \\
\text { Measure }\end{array}$ & $\begin{array}{l}\text { Unit } \\
\text { Price }\end{array}$ & Taxes & Subtotal \\
\hline & $\begin{array}{l}\text { [PWRN] } \\
\text { Prosion }\end{array}$ & $\begin{array}{l}\text { [PWRN] } \\
\text { Prosion }\end{array}$ & $\begin{array}{l}\text { 09/09/2019 } \\
21: 05: 31\end{array}$ & & & $1.000,0$ & 0,0 & 0,0 & g & 120 & & Rp $120.000,00$ \\
\hline
\end{tabular}

Fig.6. Purchase Order Documents

Figure 6 explains the display in making a Purchase Order. Then the Purchase user can directly send to the vendor by selecting the "Send PO by Email" button. The vendor bill is made by the purchase user when the goods from the vendor have arrived at the company. The function of the Lock button is that it can change to lock and unlock the purchase data, therefore it cannot be edited except for the purchase manager.

Run Scheduler

When you run the schedulers, Odoo tries to reserve the available stock to fulfill the existing pickings and verify if some reordering rules should be triggered.

\section{Run Schedulers Cancel}

Fig.7. Run Scheduler Display

Figure 7 is used by the Inventory user to call the reordering rule function. Then, the information is forwarded to the purchasing department. In this case, the
Purchasing module functions to create POs for Vendors which starts with making material procurement.

\section{MO/00012}

\begin{tabular}{l|l} 
Product & $\begin{array}{l}\text { Custom Kain (Bahan Uniform, } \\
\text { Mudah) }\end{array}$ \\
Quantity To Produce & $10,0 \mathrm{~m}$ Update \\
Bill of Material & $\begin{array}{l}\text { Custom Kain } \\
\text { Routing }\end{array}$ \\
\hline
\end{tabular}

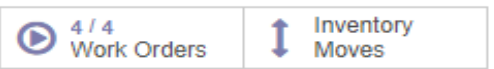

Deadline Start

04/09/2019 16:20:22

Responsible

Administrator

SO020

\begin{tabular}{|c|c|c|c|c|}
\hline Consumed Materials & Finished Products & & & \\
\hline Product & Unit of Measure & To Consume & Reserved & Consumed \\
\hline [BNG] 60/2 & $\mathrm{kg}$ & 2,0 & 2,0 & 2,0 \\
\hline [OBT] Fixanol & Liter(s) & 2,0 & 2,0 & 2,0 \\
\hline
\end{tabular}

Fig.8. Manufacturing Order Documents 
Figure 8 is a display that shows if all stages of Work Orders have been completed. Then, the product ordered has been completed. Next, the Manufacture user chooses the Mark as 'Done' which is a button to declare that the production process has been completed and the goods move to the Inventory for delivery to the Customer.

\section{WH/OUT/00020}

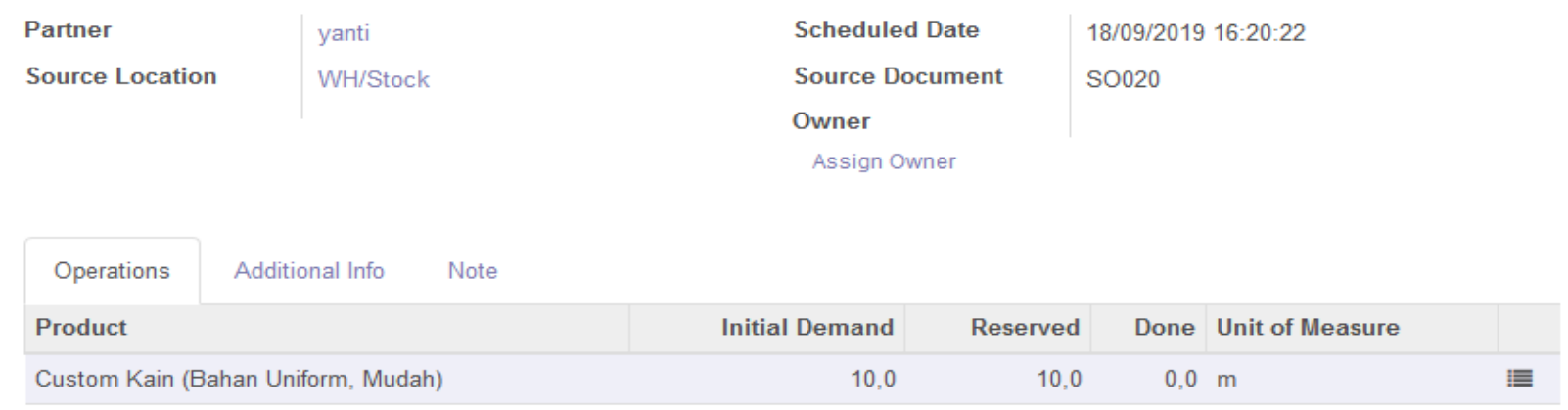

Fig.9. Detail Delivery Orders

Figure 9 is a display labeled WH / OUT / 000020 can be interpreted as data orders for products that are taken out of the company. The display is an order data sourced from SO020, therefore the Inventory users will validate it when it is shipped.

\section{B. Questionnaire Result}

The testing of this study was conducted on 10 respondents who were employees of the marketing department, administrators, material purchases, warehouses, and production. It used the UAT method to determine the amount of acceptance of system implementation. The test document contains 5 aspects and consists of 18 statements. Besides, the test also uses a Likert scale of 1 to 5 the results are shown in the following table 1 .

Table 1. Results of the Questionnaire

\begin{tabular}{|c|c|c|c|c|c|}
\hline \multirow{3}{*}{ Item } & \multicolumn{5}{|c|}{ Frequency } \\
\hline & 1 & 2 & 3 & 4 & 5 \\
\hline & Disagree & Not agree & Quite agree & Agree & Strongly agree \\
\hline Content Aspect & & & $23 \%$ & $67 \%$ & $10 \%$ \\
\hline Module Aspects & & & $47 \%$ & $53 \%$ & \\
\hline Aspects of Multimedia Elements & & & $4 \%$ & $74 \%$ & $22 \%$ \\
\hline Navigation Aspects & & $3,3 \%$ & $23,3 \%$ & $63,3 \%$ & $10 \%$ \\
\hline Usability Aspect & & & $7,5 \%$ & $65 \%$ & $27,5 \%$ \\
\hline
\end{tabular}

Table 1 is the results of the questionnaire on testing aspects. It obtained the largest percentage of $67 \%$ where respondents agree that the Content Aspect displayed was clear and easy to understand, besides, related to the company's business processes. Furthermore, $53 \%$ of respondents agree that the Module Aspects designed are easy to obtain and understand. There are $74 \%$ of respondents agreed that the Multimedia Element Aspects were appropriate in the use of fonts, colors, and buttons, as well as a good graphic display. Also, 63.3\% of respondents think that the Navigation Aspect that was designed produces a system flow that is easy to understand, and the use of links that are accessed easily. Lastly, 65\% of respondents agreed on the Usability Aspect which the Odoo system is useful for company departments, such as Sales, Material Purchasing, Warehouse, and Production.

Furthermore, the UAT testing was conducted to determine the success level of the Odoo system implementation by using a Likert's Summated Rating
(LSR) scaling technique on the results of the questionnaire.

1. Total responses on the questionnaire results for each aspect:

Total responses $1=0$

Total responses $2=1$

Total responses $3=33$

Total responses $4=118$

Total responses $5=28$

2. Total score of responses to questionnaire results:

Total score of response

Total score of response 2

Total score of response 3

Total score of response 4

Total score of response 5

Overall total score $\quad=0+2+99+472+140=$

713 (score on LSR interpretation)

3. Total score for each respondent :

Maximum score

: $5 \times 18$ statements $=90$ 

Minimum score $: 1 \times 18$ statements $=18$
Median score : 2 x 18 statements $=36$
$\begin{array}{ll}\text { Quartile I score } & : 3 \times 18 \text { statements }=54 \\ \text { Quartile III score } & : 4 \times 18 \text { statements }=72\end{array}$

4. Total score for all respondents :

$\begin{array}{ll}\text { Maximum } & : 90 \times 10 \text { respondents }=900 \\ \text { Minimum } & : 18 \times 10 \text { respondents }=180 \\ \text { Median } & : 36 \times 10 \text { respondents }=360 \\ \text { Quarter I } & : 54 \times 10 \text { respondents }=540 \\ \text { Quarter III } & : 72 \times 10 \text { respondents }=720\end{array}$

Furthermore, the results of implementation calculations with a range of $720<$ Score $<900$, which means very positive (The system is considered as successful). If $540<$ Score $<720$, it means positive (The system is considered to be quite successful). If 360 $<$ Score <540, it means negative (The system is considered to be less successful). If $180<$ Score $<360$, it means very negative (The system is considered as unsuccessful).

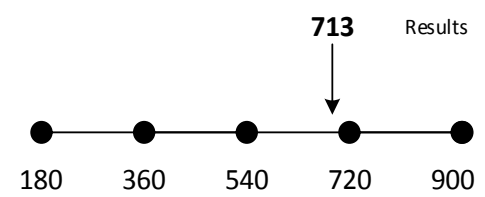

Fig.10. The result of LSR Interpretation
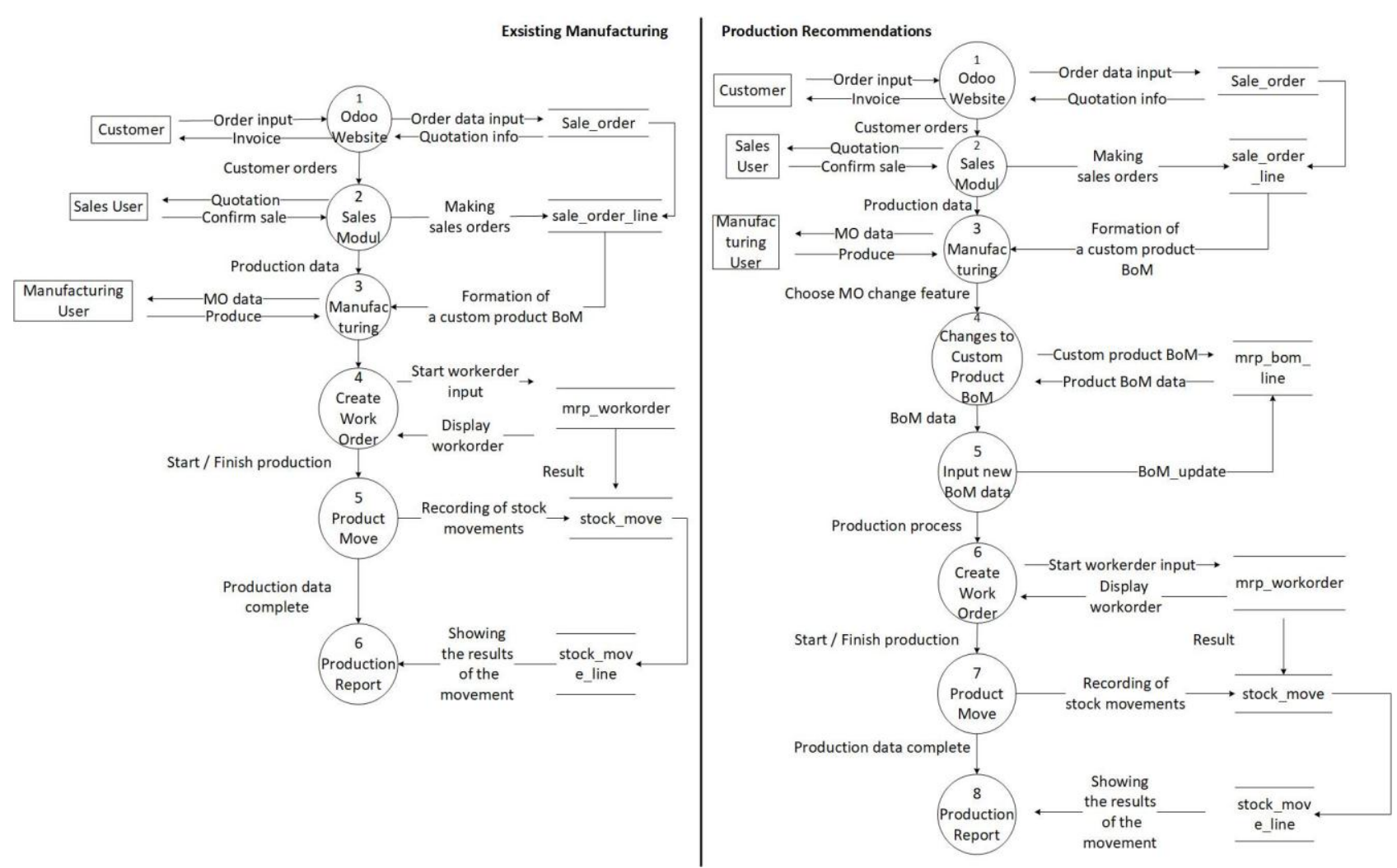

Fig.11. DFD Level 1 Model Button Recommendations

Figure 11 covers the process of data flow that is illustrated by using the DFD level 1 model. In the existing MRP section, there are 6 processes where there is no material conversion process. Then, on the right side
The total assessment score that is obtained from 10 respondents is $540<713<720$, thus the value is positive and the system implementation tested was quite successful.

\section{Recommendations}

The implementation of Odoo is considered quite successful, but there are deficiencies in the Manufacturing module, such as when editing the material needs of the product. It is because the needs of companies who want to make changes in production data for custom products need to be adjusted to customer demand. The recommendation proposed in this study is developing button features for editing material in the Manufacturing Order display. The current implementation of custom products is a coloring material that is generally added without using color variants. It is due to limitations on Odoo 11 tools that cannot edit BoM on manufacturing, therefore the type of color requested by the customer cannot be tracked in the system. Furthermore, to know the process of existing manufacture and recommendations, it can be seen in Figure 11. The design of this recommendation is done by adjusting the Odoo architecture by using DFD level 1 and making the desired display design. 


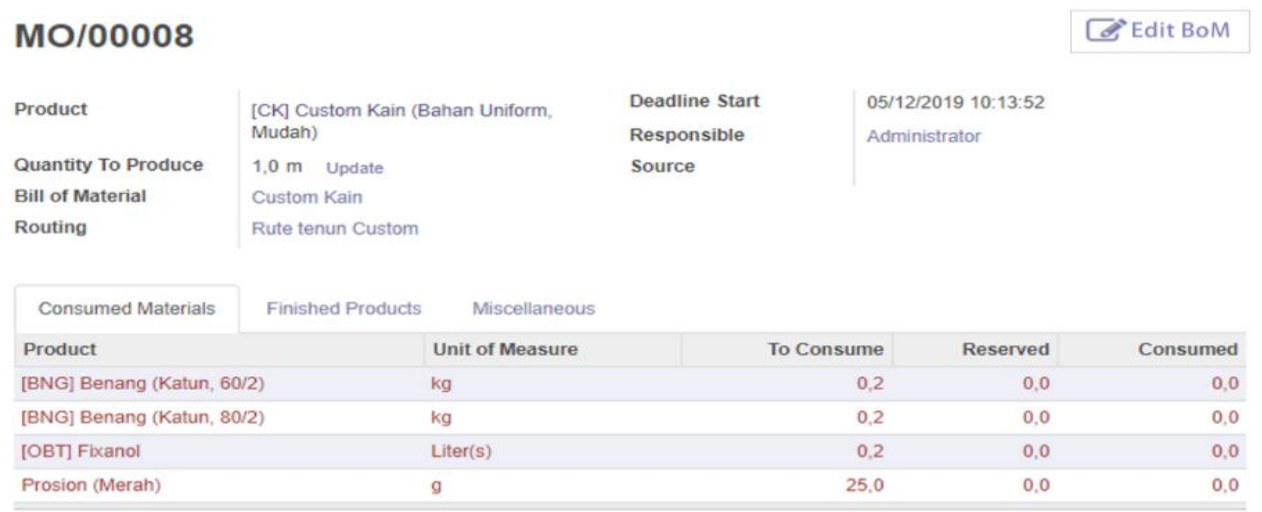

Fig.12. Recommendation of BoM Edit Button

Figure 12 is a display of manufacturing orders that have been stored and not yet produced. In BoM, you can see 4 products that are used. If the customer wants to add green coloring, then the editing is done by selecting the Edit BoM button.

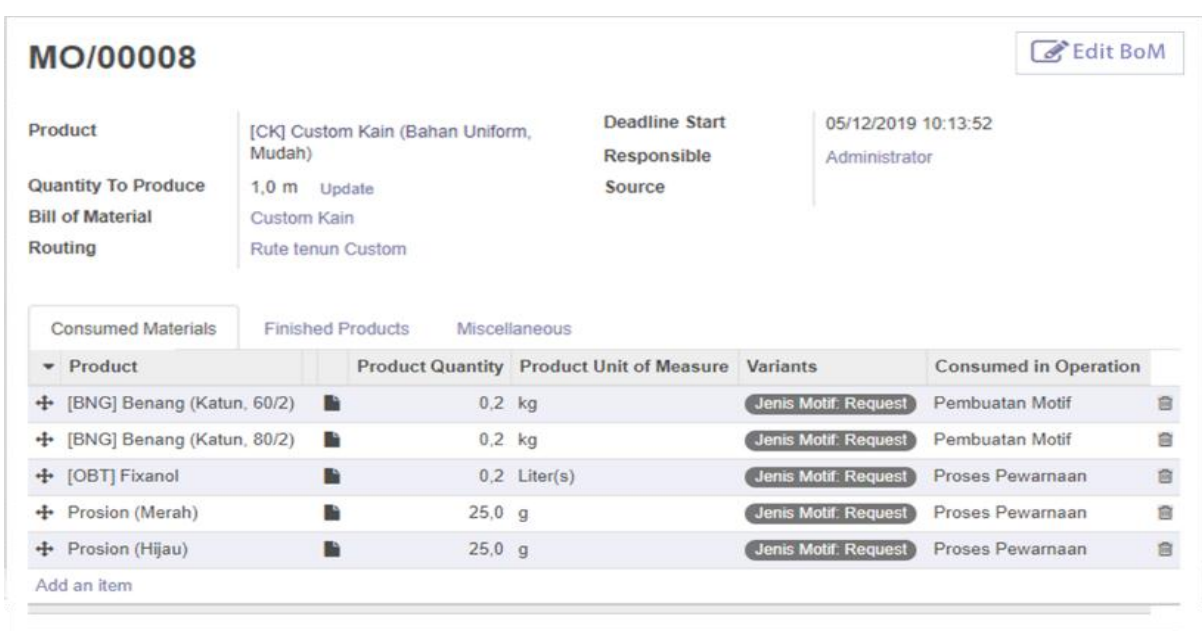

Fig.13. Document for editing BoM on MO

Figure 13 is the display when the BoM edit button is selected. The tab appears for the material product used and it can also add products or delete products.
Furthermore, the data is automatically stored and changed in the database.

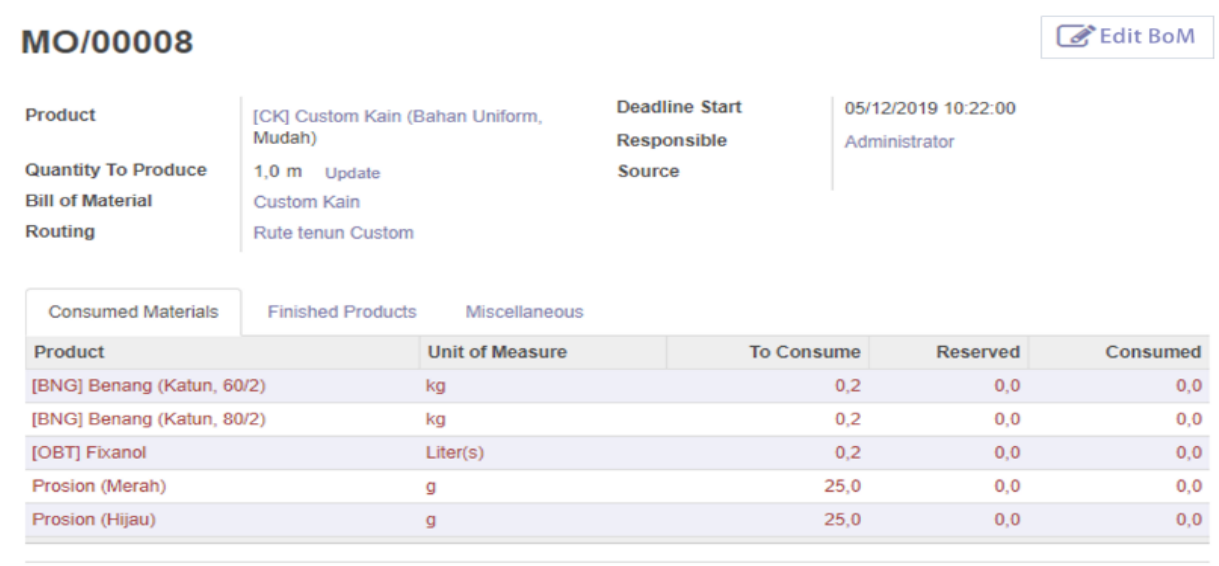

Fig.14. The edited MO document

Figure 14 is the display of manufacturing orders that are now changing and it can meet customer needs, especially when they want to add some color variants to the desired custom woven fabric. 


\section{CONCLUSION}

Implementation of the system with the concept of ERP in an organization is a form of an efficient strategy for performance efficiency and improving organizational effectiveness. There are many ERP software that can be implemented in MSMEs, one of them is Odoo Software. The Odoo software is not only easy to get for free, but it can also be adjusted to the needs of MSMEs. The Odoo is applied to XYZ Weaving in the SCM area where it was run conventionally. Then, it becomes integrated with the use of one system. The results of this study by using the UAT method for measuring the feasibility of Odoo software covers 5 aspects with the greatest frequency of responses is 'agree'. The system is stated to be accurate from the measurements of content aspects (67\%) and module aspects $(53 \%)$. One of them can be seen from the information displayed in the inventory module that has the 'Reordering Rules' function. The 'Reordering Rules' is a safety stock model that can accurately predict the number of material purchases according to the needs of the warehouse when the stock is below the minimum. Furthermore, the system is stated to be efficient from the measurements of the Multimedia Element aspects (74\%) and Navigation aspects $(63.3 \%)$. It can be seen from the easiness in managing reports and the existence of documents that can be distributed to all divisions of the company. The system is stated to be reliable based on the measurements of the Usability aspect (65\%). It results in the integration of Odoo software that gives a good impact on minimizing the problems faced by the XYZ Weaving Company, for example discovering stock data easily and monitoring the course of production and distribution processes. Besides, the results of the questionnaire show that the implementation of Odoo version 11 had a limited scope where the production process cannot be edited to add material. Therefore, a recommendation of flows for making edit button is produced to add the required material. For further development, a security audit is needed for the entire ERP utilization process in XYZ Weaving.

\section{REFERENCES}

[1] Kemenperin.go.id, "Nilai Ekspor Industri Tenun dan Batik Lampaui USD 151 Juta," Kementrian Perindustrian Republik Indonesia, 2017. [Online]. Available: http://www.kemenperin.go.id/artikel/17377/Nilai-EksporIndustri-Tenun-dan-Batik-Lampaui-USD-151-Juta.

[2] R. Akbar and J. Juliastrioza, "Penerapan Enterprise Resource Planning (ERP) untuk Sistem Informasi Pembelian, Persedian dan Penjualan Barang pada Toko EMI GROSIR dan ECERAN," J. Nas. Teknol. dan Sist. Inf., 2015.

[3] F. Fui and H. Nah, Enterprise Resource Planning Solutions \& Management. IRM Press, 2002.

[4] M. Haddara, "ERP systems selection in multinational enterprises: A practical guide," Int. J. Inf. Syst. Proj. Manag., 2018.
[5] D. Fernandez, Z. Zainol, and H. Ahmad, "The impacts of ERP systems on public sector organizations," Procedia Comput. Sci., vol. 111, pp. 31-36, 2017.

[6] T. H. Davenport, "Putting the enterprise into the enterprise system.," Harv. Bus. Rev., vol. 76, no. 4, pp. 121-131, 1998.

[7] R. Jaiswal, "Evaluation Of Open Source Erp For Small And Medium Scale Industries," Abhinav Int. Mon. Ref. J. Res. Manag. Technol., vol. 3, no. 10, 2014.

[8] E. F. Monk and B. J. Wagner, Concepts In Enterprise Resource Planning, 4th ed. Course Technology, Cengage Learning, 2013.

[9] Noprianto, W. Budhysantika, and Widoyo, Dasar-dasar OpenERP: Sisi Teknikal Dan Cotoh Kasus. 2014.

[10] A. M. Lund, "Measuring usability with the USE questionnaire," Usability interface, 2001.

[11] F. D. Davis, "User acceptance of information technology: system characteristics, user perceptions and behavioral impacts," Int. J. Man. Mach. Stud., vol. 38, no. 3, 1993.

[12] S. AboAbdo, A. Aldhoiena, and H. Al-Amrib, "Implementing Enterprise Resource Planning ERP System in a Large Construction Company in KSA," Procedia Comput. Sci., vol. 164, pp. 463-470, 2019.

[13] C. K. N. C. K. Mohd and F. Shahbodin, "Personalized Learning Environment: Alpha Testing, Beta Testing \& User Acceptance Test," Procedia - Soc. Behav. Sci., 2015.

[14] I. Antoniadis, T. Tsiakiris, and S. Tsopogloy, "Business Intelligence During Times of Crisis: Adoption and Usage of ERP Systems by SMEs," Procedia - Soc. Behav. Sci., vol. 175, pp. 299-307, 2015.

[15] I. Winda, I. Made, and I. Ketut, "Developing Manufacturing Application using Enterprise Resource Planning Concept," Int. J. Comput. Appl., 2017.

\section{Authors' Profiles}

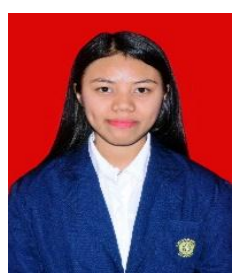

Julianty Surasma Surung was born in Soe, East Nusa Tenggara on July 18, 1997. She is one of the students in Information Technology, Udayana University, Bali, Indonesia who is concentrating on Business management.

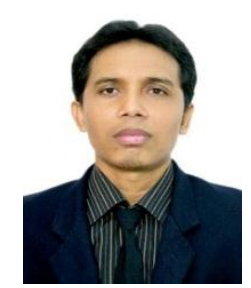

I Putu Agung Bayupati received the Bachelor of Engineering degree in Electrical Engineering from Udayana University, and a Master of Engineering degree in Information Technology from Bandung Institute of Technology and D.Eng degree in Electrical Engineering and Computer Science from Kanazawa University in 2001, 2006 and 2012 respectively. He joined to Udayana University in 2003 as a lecturer. His research interest is in intelligent signal processing, computer vision and image processing. 


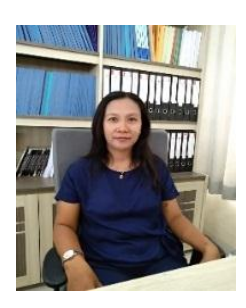

Gusti Agung Ayu Putri is a lecturer at the study program of Information Technology, Faculty of Engineering, Udayana University-Bali. She received an M.Eng. in Electrical Engineering with a

focused study of Informatics and Computer Systems from Gadjah Mada University in 2005. She is interested in the research of context-awareness and Management Information Systems.

How to cite this paper: Julianty Surasma Surung, I Putu Agung Bayupati, Gusti Agung Ayu Putri, " The Implementation Of ERP In Supply Chain Management On Conventional Woven Fabric Business", International Journal of Information Engineering and Electronic Business(IJIEEB), Vol.12, No.3, pp. 8-18, 2020. DOI: 10.5815/ijieeb.2020.03.02 